\title{
ИНТЕРНЕТ-РЕСУРСЫ В ОБУЧЕНИИ РУССКОМУ ЯЗЫКУ КАК ИНОСТРАННОМУ
}

\section{Лариса Александровна Шабалина}

Новосибирский государственный медицинский университет, 630075, Россия, г. Новосибирск, ул. Медкадры, 5, ст. преподаватель кафедры лингвистики и межкультурной коммуникации, тел. (383)226-24-64, e-mail: larisa_shabalina@mail.ru

\section{Ксения Александровна Втюрина}

Новосибирский государственный медицинский университет, 630075, Россия, г. Новосибирск, ул. Медкадры, 5, преподаватель кафедры лингвистики и межкультурной коммуникации, тел. (383)226-24-64, e-mail: ksenia.tmsh@ gmail.com

В статье рассматриваются особенности использования вспомогательных интернетресурсов в практике преподавания РКИ. Перечислены задачи, которые решают интернетресурсы в лингводидактической деятельности. Обозначены трудности, возникающие в практике применения интернет-ресурсов в обучении РКИ.

Ключевые слова: РКИ, Интернет, интернет-ресурсы, лингводидактическая деятельность.

\section{INTERNET RESOURCES IN TEACHING RUSSIAN AS A FOREIGN LANGUAGE}

\section{Larisa A. Shabalina}

Novosibirsk State Medical University, 5, Medkadry St., Novosibirsk, 630075, Russia, Senior Lecturer, Department of Linguistics and Intercultural Communication, phone: (383)226-24-64, e-mail: larisa_shabalina@mail.ru

\section{Ksenia A. Vtyurina}

Novosibirsk State Medical University, 5, Medkadry St., Novosibirsk, Russia, 630075, Lecturer, Department of Linguistics and Intercultural Communication, phone: (383)226-24-64, e-mail: ksenia.tmsh@gmail.com

The article is devoted to peculiarities of using of auxiliary Internet resources in teaching Russian as a foreign language. The authors enumerate tasks that are being solved in the lingvodidactic activity by means of Internet resources and point out some difficulties that arise in the Internet resources usage when teaching Russian as a foreign language.

Key words: Russian as a foreign language, Internet, Internet resources, lingvodidactic activity.

Современное общество развивается в эпоху информатизации. Информационные технологии активно применяются во всех сферах человеческой деятельности, в том числе в сфере образования. Сегодня не только нормативные документы рекомендуют использовать информационные технологии в учебном процессе, но и сама вовлеченность современного обучающегося в интернетпространство, в котором он общается, получает информацию, способствует развитию коммуникативных навыков и когнитивных процессов. 
В области преподавания русского языка как иностранного (РКИ) интернет с его ресурсами занял особое место. Интернет-ресурсы обеспечивают возможность реального общения на изучаемом языке, предоставляют доступ к аутентичным материалам и большому числу учебных ресурсов в различных форматах.

В лингводидактической деятельности интернет-ресурсы решают следующие задачи:

- формируют навыки чтения на материале текстов разной степени сложности;

- совершенствуют умение монологического и диалогического высказывания;

- позволяют пополнять словарный запас, в том числе лексикой языка осваиваемой специальности;

- позволяют знакомить обучающихся с культуроведческими знаниями.

Традиционно выделяют следующие сферы применения интернет-ресурсов в лингводидактической деятельности: как источник информации, как средство коммуникации, как средство обучения.

В качестве источника информации интернет-ресурсы можно использовать как неограниченное количество аудио-/ видео-/ текстовых материалов на различных языках (сайты, веб-страницы популярных деятелей культуры, карты, библиотеки, журналы и т. д.). К источникам информации можно отнести разнообразные поисковые системы (Google, Яндекс и т. п.), специализированные порталы, тематические сайты, навигацию, ориентированные на познавательные, развлекательные и профессиональные потребности пользователей. Можно выделить справочно-информационные ресурсы: «Грамота.ру», «Национальный корпус русского языка», различные энциклопедии и словари, переводчики; информационно-образовательные порталы: «Русский язык для всех», «Киберленинка», «Златоуст», «Russian for everyone», Youtube-канал «РКИ для всех», ru.coursera.org.

Интернет-ресурсы как средство коммуникации предстают в форме информационно-коммуникативных веб-порталов и веб-сайтов, позволяющих пользователям совершать интернет-коммуникацию и получать различные интернетуслуги. К средствам коммуникации можно отнести электронную почту, социальные сети, мессенджеры, например, WhatsApp, подкастинг «Say it in Russian», «A taste of Russian», блоги и т. д. Электронная переписка с преподавателем или сокурсниками может быть реализована как учебная, так и практическая, т. е. реальная, касающаяся учебного процесса. На практике отмечается, что интернет-коммуникация со студентами является эффективной языковой практикой, где можно увидеть прогресс учащегося.

Как средство обучения интернет-ресурсы становятся базой для подготовки по дисциплине. К ним относятся различные учебно-методические комплексы и учебные пособия, программы, виртуальные образовательные среды, программы для разработки и размещения методических материалов, создания отчетности и успеваемости студентов, личные кабинеты/ страницы студентов и препо- 
давателей, дистанционное обучение. Все эти ресурсы предстают как конструируемые или готовые блоки с информацией по учебному процессу.

Студентами 1 курса НГМУ было проведено исследование, касающееся востребованности выделенных интернет-ресурсов у обучающихся. Согласно опросу около 82 \% респондентов (иностранные студенты 1-3-х курсов НГМУ, а также студенты - носители русского языка) активно пользуются интернетресурсами в процессе изучения русского языка. В результате проведенного исследования стало очевидно, что существует потребность в современных образовательных интернет-ресурсах при изучении русского языка, и, что важно, подобные материалы имеют положительные отзывы среди студентов-пользователей.

Все указанные материалы могут быть использованы как дополнительный аутентичный материал (языковой и культурологический), как иллюстративный материал на занятиях по РКИ при изучении лексики и грамматики, коммуникативных тем, а также для сбора информации при подготовке проектов и исследовательских работ. Однако нужно обратить внимание на то, что в образовательном процессе необходимо овладеть специальными навыками поиска и адаптации полученной информации из интернет-ресурса.

Следует отметить трудности, возникающие, на наш взгляд, в практике применения интернет-ресурсов в обучении РКИ.

1. Недостаточная, а зачастую низкая способность обучающихся ориентироваться в сетевом пространстве. Опыт работы со студентами-иностранцами показывает, что большинство из них не знакомы с интернет-ресурсами, на которых представлена качественная и достоверная информация по русскому языку как иностранному. Поэтому преподавателям приходится знакомить обучающихся с теми интернет-ресурсами, которые они могут использовать как для получения информации, так и для общения и обучения.

2. Отсутствие условий для работы с интернет-ресурсами непосредственно на занятиях. Если выход в Интернет осуществляется во время занятия, то у преподавателя должна быть возможность продемонстрировать, как работать с различными интернет-ресурсами. А для этого нужен специально оборудованный кабинет.

Также не во всех вузах есть возможность пользоваться сетевыми учебниками и учебными пособиями, которые разрабатываются для дистанционного изучения предмета. Цифровой формат учебных материалов и пособий по РКИ, ресурсов справочного характера и тестовых систем - это для многих вузов скорее в будущем в практике преподавания РКИ, чем в настоящем.

3. Недостаточная компетентность преподавателей РКИ в области информационных технологий. Многообразие интернет-ресурсов требует от преподавателя РКИ как умений и навыков создания интернет-дидактических средств, так и отбора существующих интернет-ресурсов различной степени качества и достоверности, а также умений их адекватного применения. 
Решение дидактических задач, связанных с использованием Интернета, накладывает на преподавателя РКИ дополнительную ответственность и увеличивает время подготовки к занятиям.

4. Проблема отбора качественных текстов из Интернета. Для занятий по РКИ приходится отбирать различные тексты как дополнительный материал по определенной тематике. Особенно сложно отбирать профессионально ориентированные тексты. При отборе таких текстов необходима помощь преподавателей спецдисциплин, а это требует дополнительного времени и не всегда является возможным.

В заключение следует отметить, что интернет-ресурсы в обучении РКИ играют важную, но пока еще вспомогательную роль. Вместе с тем постоянное обращение к интернет-ресурсам формирует у иностранных обучающихся не только потребность критически осмысливать готовые тексты, но и создавать собственные. Последовательное и систематическое использование интернетресурсов в учебной и самостоятельной деятельности способствует развитию коммуникативной компетенции обучающихся и формирует сознательный подход к собственной речевой практике.

\section{БИБЛИОГРАФИЧЕСКИЙ СПИСОК}

1. Сбитнев К. В. Ресурсы сети Интернет в обучении иностранному языку // Современная филология: теория и практика : материалы III Междунар. науч.-практ. конф. Москва, 29-30 декабря 2010 г. - М. : Институт стратегических исследований, 2010. - С. 116-118.

2. Сысоев П. В., Евстигнеев М. Н. Методика обучения иностранному языку с использованием новых информационно-коммуникационных интернет-технологий: учеб.-метод. пособие. - М. : Глосса-Пресс ; Ростов на/Д. : Феникс, 2010. - 177 с.

(C) Л. А. Шабалина, К. А. Втюрина, 2020 